\title{
THE GENESIS OF ADMINISTRATIVE OFFENCES
}

\section{Popovich Ye. M.}

\section{INTRODUCTION}

Today's public consciousness regarding the concept of an administrative offense (misdemeanor) reflects its understanding of the stereotype that developed in Soviet times. Sociological studies conducted on this issue in 2010-2013 showed that employees of administrative services of internal Affairs bodies of district and city levels almost one hundred percent ( $96.75 \%$ of 1765 respondents) pointed to them as identical concepts, which are normative, fixed CAO Ukraine.

Meanwhile, in the works of a number of experts, which in varying degrees concerned the issues of the essence and content of the phenomenon with the modern name "administrative offence (offense)" we find indications for a certain inconsistency of the official Soviet doctrine of administrative offences: first, research lawyers of the Russian Empire XIX early XX centuries, and secondly, with the European administrative-legal theory and practice, third, research of the subject of administrative law and administrative legal relations in the last third of the twentieth and early twenty-first century.

Overcoming the actually existing scientific and theoretical crisis in this segment of administrative law, according to V. Kolpakov, should begin with the deepening of scientific understanding of the administrative offense and administrative offense as genetically different legal categories with the subsequent formation, firstly, the doctrine of administrative (administrative) offense; secondly, the doctrine of administrative misconduct (tort) ${ }^{1}$.

\section{Historical and legal nature of an administrative offense (misdemeanor)}

The formation of the Institute of administrative (administrative) offense with determinant features of the legal category is inextricably linked with the emergence of administrative law and administrative proceedings (administrative justice). Explain why. Purely schematic. Practice of functioning of administrative apparatus of all States shows, - Ivan Tarasov

\footnotetext{
1 Official website of the Ministry of internal Affairs of Ukraine. URL: http://www.mvs.gov.ua Official website of the Ministry of internal Affairs of Ukraine. URL: http://www.mvs.gov.ua/.
} 
wrote, - that irrespective of presence or absence of obvious, direct, conscious offenses and deviations from an office order, in activity of any administration such actions and orders which essentially violate the lawful rights and interests of citizens are always possible, are neither crimes, nor civil untruth, nor errors on service.

In such actions and orders of the administration lies the essence of the so-called "administrative untruth. In comparison with criminal untruth, administrative untruth, according to I. Tarasov, is an offense of a more subtle and complex nature. To effectively counteract administrative injustice, he considered it necessary to introduce administrative justice and create a system of administrative courts. He saw the functional purpose of administrative courts not in imposed penalties and punishments, but only in cassation or direct cancellation of illegal acts of administrative power. Responsibility by decision of the administrative court. T. Tarasov formulates as administrative responsibility that is responsibility for Commission of administrative (administrative) offense and separates it from other judicial responsibility ${ }^{2}$.

The legal properties of this lie he reduces to this:

a) it can only come from the administration, due to this, its scope is limited, on the one hand, civil untruth, and on the other - criminal untruth;

b) regardless of the scope and content of the relations that it affects, administrative untruth has a General, public (and not private) value;

c) it always takes the form of a legal administrative act of the administration exercising its powers;

d) it has the character of a potentially ongoing, repeatedly repeated lie.

Proceeding from the fact that administrative untruth is a specific encroachment on the right (it is not a crime, is not a civil untruth, is not an error in the service or a disciplinary offense), Etc. Tarasov comes to this conclusion: in order to protect the rights and interests of citizens from administrative injustice (illegal actions of the administration or administrative offenses) and ensure the rule of law in the management of the existing at the time of judicial or disciplinary responsibility is not enough to effectively counter administrative injustice, he considers it necessary to introduce administrative justice and create a system of administrative courts. In his opinion, the administrative courts will ensure by constant monitoring the legality of the orders and actions of the administration. He saw the functional purpose of administrative courts not in imposing penalties and punishments, but only in cassation or direct cancellation of illegal acts of administrative power.

\footnotetext{
${ }^{2}$ National police. A temporary web site. URL: http://www.npu.gov.ua/uk/
} 
Responsibility by decision of the administrative court. I. Tarasov formulates as administrative responsibility that is responsibility for Commission of administrative (administrative) offense and separates it from other judicial responsibility.

Administrative (administrative) offenses were called illegal unintentional acts exclusively of the administration (and not citizens) without individualized fault of a particular official, if they were not provided for in criminal law and did not have a civil wrong ${ }^{3}$.

Responsibility for administrative offenses was the restoration of the violated right, was provided by a single (at that time) type of administrative penalties-the abolition of the illegal act by the administrative justice authorities. Compensation for material damage caused by this act (action) occurred in the framework of criminal or civil proceedings. Historical analysis shows that the emergence of the concept of "administrative offense" is associated with attempts to improve criminal legislation by distinguishing criminal offenses by the degree of public danger.

This distinction was most successfully made in the French Code of 1795. It distinguished: a) crimes-acts for which corporal punishment was provided; b) misdemeanors or torts-acts for which punishments of a correctional nature were provided.

Over time, this classification has become dominant in many European countries. Gradually, the classification is simplified, but the separation of manifestations of criminally punishable illegal behavior into actual crimes and minor crimes (misdemeanors, torts), which later receive the name of criminal offenses or police offenses, or torts, remains fundamental. In Russia, it acquires practical and doctrinal significance with the introduction of the criminal and correctional punishment Ordinance (1845). In this act, the words "crime" and" misdemeanor" received the status of legal terms and began to denote different degrees of public danger acts.

Subsequently, such offenses began to be defined as administrative. Such clarification was connected with procedural features of application of punishments under the criminal legislation of the Russian Empire. According to the General provisions punitive power in Russia was concentrated in the courts. Cases of minor crimes (or misdemeanors) were considered specifically for this purpose by magistrates 'courts. But in 1889, the institution of magistrates "courts was abolished, and the functions of considering cases of misconduct were transferred to administrative bodies.

${ }^{3}$ Scientific and practical comment of section IV "Powers of police" and V "Police measures" of the Law of Ukraine "on National police"/ T. Minka, G. Mironyuk, V. Glukhoverya, etc.; for zag. ed. Kharkiv: Pravo, 2016. 178 p. 
From now on, minor crimes, or criminal offenses, which by their nature are actions of a criminal nature, begin to be referred to as "administrative offenses" ${ }^{4}$.

All of the above allows us to draw such a conclusion. Offenses that today in theory, in practice and in the legislation are understood as administrative, in theory, in practice and in the legislation of pre-revolutionary Russia were understood as unimportant crimes or offenses (police offenses, torts).

Sanctions from their Commission carried out exclusively punitive functions provided in the criminal legislation, and their essence did not change neither from an administrative order of application, nor from establishment by administrative body. In the latter case, the administrative body established the composition of the acts and the punishment for their Commission.

Understanding of concepts of administrative (administrative) offense and administrative offense (tort) which in the legal theory of the Russian Empire were formed actually according to the European standards, after October, 1917 begin to change.

In official sources, they are gradually beginning to be interpreted as synonymous terms, meaning the acts of individuals who violate the prohibitions established by the state and entail an administrative procedure for the application of penalties.

In accordance with ideological and political attitudes, a doctrinal basis is developed. Legislative consolidation of this approach gets in the Fundamentals of the USSR and the Union republics on administrative offenses [1980], in article 7 used the following wording: "administrative offense (misdemeanor) is recognized...". Thus, the position of the legislator regarding the adequacy of the concepts of "administrative offense" and "administrative offense" was fixed ${ }^{5}$.

No change this design moved to the CAO of Ukraine 1984.

So, in Soviet times, in fact, in all scientific works of both specialistsadministrative and representatives of other legal Sciences, these terms are used as synonyms.

During the time of independence, the development of issues of administrative offense (misdemeanor) retains the trends of the previous (Soviet) period and is actually carried out within the limits defined by article 9 of the administrative Code of the USSR and the commentary to it, written by L. V. Koval.

\footnotetext{
${ }^{4}$ Administrative law of Ukraine. Academic course: Studies.: In 2 vols. / Ed. Collegium: V. Averyanov (head). Kyiv: Yuridicheskaya Mysl, 2004. Vol. Common part. 584 p.

${ }^{5}$ Demsky, E. Administrative procedural law of Ukraine: studies. benefit. / E. Demsky. Kyiv: Yurinkom Inter, 2008. 496 s
} 
The analysis of numerous changes in the CAO both in Soviet times and during the years of independence of Ukraine shows that they were made to this article once - in 2001. These changes concerned only the fixation of socio-political

they did not affect the essential characteristics of the administrative offense (misdemeanor). Thus, the words "legislation" (in part one) and "current legislation" (in part two) were replaced by the words "law" and "law" respectively, and the words "state or" and "socialist" were deleted. The wording of article 9 of the CAO with the mentioned changes remains in force to this day.

He was the first in the modern history of Ukrainian administrative law to characterize administrative misconduct. P. Golosnichenko in the monograph "Prevention of selfish misconduct by means of administrative law" (1991).

In 1994, L. Koval gave the first course of lectures on administrative law since independence, in which, in comparison with the text of the commentary (1991), article 9 of the administrative Code of the Ukrainian SSR actually clarifies his position in the discussion on the concepts of public danger and harmfulness of misconduct and confirms his view on the presence of such a sign as punishability.

A. Ostapenko was the first in the Ukrainian administrative law in the work of the monographic level "Administrative delictology" (1995), offers the legislator a new definition of administrative tort:"... administrative tort is socially harmful (dangerous), illegal, guilty actions or inaction provided by the law, committed by a person in a particular place under certain conditions during the encroachment on public relations, which are protected by law."

V. Dodin in the course of lectures "administrative delictology" (1997) expresses several principled opinions on the essence of administrative misconduct. First, he notes that the administrative tort is qualitatively different from the crime, and this quality is legislatively defined the possibility of administrative responsibility for the absence of guilt ${ }^{6}$.

Today, the attention of researchers is attracted by the identification of the concepts of "administrative offense" and "administrative offense" by the legislator. Unfortunately, as a rule, in modern literature, their analysis is based on a purely linguistic and criminological interpretation of concepts without taking into account the historical roots of the appearance in law and legislation of the term "offense".

This approach has led to the conclusion that administrative misconduct is a specific type of offense for which administrative liability measures are applied.

\footnotetext{
${ }^{6}$ Administrative law of Ukraine. Academic course: Studies.: In 2 vols. / Ed. Collegium: V. Averyanov (head). Kyiv: Yuridicheskaya Mysl, 2004. Vol. Common part. 584 p.
} 
Now the first who broke the problem of the Genesis of administrative violations in the domestic legal and administrative science were V. Kolpakov. In the framework of his dissertation research "Deliktny phenomenon in administrative law of Ukraine" (2005) Kolpakov explores the historical and legal nature of administrative misconduct, ontological and epistemological approaches to the problem of administrative misconduct and a number of other problematic issues on this topic.

It is V. Kolpakov, I. Golosnichenko who can be considered the founders of the most radical, most effective and largely coinciding with the needs of modern practice of lawmaking and law enforcement, the concept of renewal of administrative-tort law and administrative misconduct, in particular.

The modern concept is based on the idea of A. Koval on a three-part system of administrative torts. He considered expedient allocation in all array of administrative offenses: a) administrative offenses of the increased degree of public danger; b) administrative offenses of insignificant public danger; b) administrative violations of primary character which are socially dangerous only in "General weight".

Taking into account this concept, scientists develop the rationale for the formation in the future of the institution of criminal misconduct, and in the modern, transitional period-the defendant's misconduct. To this end, a new codified act-the Code of Ukraine on defendants and administrative offenseswas proposed and developed at the time.

\section{The concept and signs of an administrative offense}

The society has a significant number of different kinds of legally binding rules, standards, requirements that are established or authorized by the state. Such rules are intended to regulate public relations, normalize certain procedures, actions, law enforcement and proper discipline in certain areas of activity. The rules of conduct established by the state directly affect the interests of all or most citizens, enterprises, institutions and the state as a whole ${ }^{7}$.

Such mandatory rules include rules of conduct in public places, traffic rules, rules of labor protection and safety, requirements of administrative regimes, sanitary, the procedure for the formation of prices and tariffs, licensing procedures, fire requirements, customs procedures, etc.

Compliance with these rules, norms, standards, requirements and procedures corresponds to the public interest, that is, the interests of everyone and the state as a whole, and their violation contradicts them and causes harmful and socially dangerous consequences.

\footnotetext{
${ }^{7}$ National police. A temporary web site. URL: http://www.npu.gov.ua/uk/
} 
All these rules shall be established by the laws and by-laws of the subjects of public administration, issued by them within their competence. One of the properties of these rules is that they are protected by administrative sanctions, and their violation is recognized as administrative offenses.

In the scientific literature for more than 50 years there is a discussion about the concept of which it is necessary to designate the fact of behavior that does not comply with the generally established rules, violates them. The legislator uses two concepts: an administrative offense and an administrative offense (article 9 of the administrative code), which already suggests the idea of the correlation of these concepts. In addition, there is the concept of administrative tort. The existence of these three terms is explained by an attempt to distinguish between administrative and criminal cases, as well as violation of labor discipline ${ }^{8}$.

General features and legal characteristics of administrative offenses contained in the administrative Code of Ukraine. The analysis of articles of the code shows that the legislator uses two approaches to fixing of signs of an offense which is recognized administrative.

In the first case, a list of specific features is provided. Thus, according to article 9 of the administrative Code, an administrative offense is an illegal, guilty (intentional or careless) action or inaction that encroaches on state or public order, property, rights and freedoms of citizens, on the established order of management and for which the legislation provides for administrative responsibility.

In the second case, the legislator uses a term that is a generalized abstraction. Denotes not specific actual actions and their consequences, and the results of the scientific theory of administrative misconduct. This generalized term is the legal composition of an administrative offense. For example, article 247 of the administrative code, "Circumstances precluding the proceedings of an administrative offense" States that the proceedings of an administrative offense cannot be initiated, and started to be closed in the absence in act of structure of an administrative offence.

From this it follows that the composition of the offense is a set of its features that allow among all manifestations of illegal behavior to distinguish administrative offenses.

Signs characterize the General socio-psychological nature of an act, recognized as an administrative offense.

${ }^{8}$ Scientific and practical comment of section IV "Powers of police" and V "Police measures" of the Law of Ukraine "on National police"/ T. Minka, G. Mironyuk, V. Glukhoverya, etc.; for zag. ed. Kharkiv: Pravo, 2016. 178 p. 
Elements of the legal composition solve another problem, they allow to qualify the acts as illegal and bring the perpetrators to administrative responsibility if the persons are delinquent.

Thus, the signs of an offense are the result of practical activity, empirical knowledge, the truth of fact, and the legal composition is the result of scientific activity, theoretical knowledge, the truth of reason ${ }^{9}$.

According to V. Kolpakov, the criteria for classifying acts as administrative torts are: a) the presence of public danger in the act and its characteristics; b) violations of public interests by the actions of a person; c) the absence of such a sign in the act as a violation of actually existing contractual obligations.

We will use these concepts as identical.

The following General legal signs characterize an administrative offense: first, it is an action or inaction - that is, behavior, act, and act of external relation of a person to reality, other persons, and the state society. Namely, the act, not thoughts, desires or other similar manifestations of mental activity of people;

Action - the active form of behavior of the person directly connected with non-performance of the legal instruction in the form of an obligation or legal requirement, violation of the ban, rule, norm, standard (for example, small hooliganism, unauthorized occupation of the land plot, violation of traffic regulations, illegal trade activity, arbitrariness).

Inaction is a passive form of behavior, which is reflected in the failure of a person to perform those actions that she should and could perform as a result of the duties assigned to her (for example, evasion of filing a Declaration, contempt of court, failure to comply with the legal requirements of the Prosecutor).

Illegality is the Commission of an act that violates the generally binding norms and rules of administrative and other branches of law (labor, land, financial, etc.), protected by measures of administrative coercion, or Vice versa does not commit the action that must be taken. Wrongfulness means that a legal norm prohibits a particular action.

For example, public calls for failure to comply with the legal requirements of a police officer are prohibited by article 185-7 of the CAO. In addition of the wrongfulness of States and when the offence is failure to comply with the requirements of the authorized body on elimination of violations of law (failure to perform the requirements of the bodies exercising state sanitary control, failure to comply with lawful requirements of the police);

9 Administrative law of Ukraine. Academic course: Studies.: / T. Kolomoets. Kyiv: Yurinkom Inter, 2011. 576 p. 
- guilt which assumes the presence of a person's independent mental attitude to the relevant act and its consequences. Such an act as a manifestation of the will and consciousness of a person must always be guilty, that is, committed intentionally or by negligence. When there is no guilt, the act cannot be recognized as an offence;

- administrative punishability, which means that a specific illegal, guilty act will be recognized as an administrative offense only when the legislation provides for an administrative sanction for its Commission;

- antisocial orientation (this feature is often identified with public danger or public harm). Any violation of the law, encroaching on the established law and order, entails him one or another harm, violates the order, consistency, harmony of management relations. At the same time, a negative result can be manifested both in reality (petty theft) and in creating conditions for the occurrence of harm (violation of sanitary and hygienic and sanitary anti-epidemic rules). According to the degree of social significance, an act that harms the legitimate interests of the state, FL, JL is anti-social.

In this context, it should be noted that in the legal literature there are several points of view as to whether an administrative offense is socially dangerous or socially harmful.

The first concept (public danger administrative tort) is based on the fact that all illegal acts and crimes, and administrative or disciplinary or civil offenses is to a certain extent socially dangerous. That is, all of them pose a threat to the normal functioning of society; violate generally recognized rules, norms and standards ${ }^{10}$.

This approach is reflected in the position of the legislator: there are situations when acts that are recognized as crimes are further recognized as administrative offenses, or Vice versa. An example is petty hooliganism, which was recognized as a crime, then as an administrative violation or smuggling, which was initially recognized as an administrative tort, and now it is a crime under the criminal code of Ukraine. As we can see, the legal properties of these acts did not change, but only their legal assessment changed. A landmark in this sense is speculation, which was previously recognized as a tort, and now is a type of economic activity.

The definition of the concept of crime (article 2, 11 of the criminal code of Ukraine), administrative offense provides for the differentiation of these concepts is taking into account the degree of public danger.

The second concept (harmfulness of administrative offenses) is based on the fact that administrative offenses are a special type of offense, and their Commission has no public danger, but only entails harmful consequences.

${ }^{10}$ National police. A temporary web site. URL: http://www.npu.gov.ua/uk/ 
The legislator also supports this concept: in articles 10,11 of the CAO, where it is a question of committing an offense intentionally or carelessly, it is a question of harmful consequences. Article 259 of the CAO States that the harm may be moral, physical or property.

V. Kolpakov proposes to fundamentally change the approach to this problem. The refusal to consider the ratio of public danger and harm from the standpoint of their specific weight in certain groups of torts and the application of ontological-epistemological approach to the tort as a legal phenomenon, allowed us to come to the following conclusion: harm ontological category inherent in the act; public danger - epistemological category inherent in the offense.

The existence of harm, as a rule, is established by the description which in itself already acts as the proof of harmfulness of the corresponding act. Public danger is an epistemological category. It cannot be established by an ontological description of what happened. It is proved by the investigation of all the signs and characteristics of the fact of reality, and in our case - the offense. Research of all complex of properties of offense is carried out in the corresponding organizational forms-cases on administrative offenses. Such cases are essentially epistemological impressions of a particular act. Investigation of the case is the knowledge (research) of the fact of reality, in the ontology of which there were signs of tort.

The above indicates that the existence of these competing concepts is, rather, the theoretical nature of these views, and in practice the property of all concepts is used, where they rationally combine, complement each other $^{11}$.

\section{Types of administrative offenses}

Specific types of administrative offenses are grouped in eleven chapters of the special part of the administrative Code of Ukraine and other legislative acts.

As already noted, the basis of such a grouping is based on two criteria, or as scientists believe, the object-industry principle.

At the same time, in administrative and legal science, administrative offenses are divided into simple and complex.

A simple act is a single one-time (one-act) action or short-term inactivity (for example, drinking alcohol in public places, theft or stowaway).

A complex wrongful act may consist of several independent actions and be stretched over time. There are the following complex actions:

11 Kolpakov V. Administrative responsibility (administrative-tort law): studies. no. / V. Kolpakov. Kyiv: Yurinkom Inter, 2008. 256 p. 
- with two different actions (for example, petty speculation, combining buying and reselling for profit);

178) those that consist of alternative actions (for example, committing domestic violence, failure to comply with a protective order or failure to undergo a remedial program (art. 173-3); drinking alcoholic beverages in public places or appearing in public places drunk (art. Each of the alternative actions in such cases is in itself a sufficient basis for bringing to administrative responsibility. However, a person does not commit a new offense if he consistently performs all prohibited actions specified in the disposition of the legal norm;

- those, that consist of teams action-speech about them can go in those cases, when objective side offense in as a constructive a sign of characterizes repetitiveness action, as would she not was called: in camping on champion repetitiveness, systematicity, viciousness and the like (violation of rules content cats and dogs (St. 154), repeated violation by the official of rules and instructions on safe conduct of works, malicious disobedience (185), etc.);

- continuing offenses, that is, those that began with any illegal action or inaction, then continue continuously by non-performance (violation) of duties (for example, storage and carrying of hunting weapons without permission (Art. 190), individual violations of fire safety rules (art. 120), passport rules (Art. 197 Accommodation without a passport), rules of military registration (210), etc.);

- continuing offenses, that is, those that consist of several identical illegal actions related to each other and aimed at achieving a common goal, and which together form a single administrative offense. Such an offense is committed not continuously, but in separate episodes, internally closely related, but separated in time, which act as links in a chain (for example, individual cases of malicious failure of parents to raise and educate children (art. 184), violation of the rules of administrative supervision (art. 187), systematic violation of the rules of hunting, prostitution (art. 181-1), etc.).

Depending on the presence of harmful effects emit:

- formal structure of an offense-such which in the design does not provide as a result of its Commission of approach of any specifically-certain socially dangerous or harmful consequence. Only the fact of violation of this or that rule or norm is ascertained (for example, violation of sanitary and hygienic rules (Art. 42), violation of rules of land use, small hooliganism (art. 173), malicious disobedience (art. 185), etc.).

- the material composition of an administrative offense includes, in addition to the illegal action, a mandatory offensive as a result of their Commission of socially dangerous or harmful consequences (for example, 
art. 89 CAO Cruelty to animals; art. 124 violation of traffic rules, resulting in damage to vehicles, goods, roads, etc.; art. 170 administrative Code Noncompliance with standards during transportation, storage and use of products);

- Most administrative offenses are characterized by formal compositions $^{12}$.

Domination of formal structures is directed on prevention of administrative offenses, prevention of approach of real harmful consequences.

In the qualification of material warehouses, the causal link between the wrongful act and the harmful consequences must be clearly traced. In some cases, their size serves as a criterion for the qualification of an illegal act as an administrative offense, or as a crime (for example, theft, violation of currency rules, possession of drugs, smuggling, etc.).

The content of the objective party may include the nature of the repetition of the act:

- repetition is Commission by the same person within a year of a homogeneous offense for which it was already subjected to administrative penalty;

- repeated - Commission of two or more homogeneous administrative offenses provided by a specific article of the administrative Code (Art. 178. Clever drinking beverages in public places and emergence in public places in a drunken state). It qualifies as a single offense;

- malice characterizes persistence, clearly expressed unwillingness of the offender to obey repeatedly expressed legal requirements, warnings of the authorized person, the representative of the power (malicious disobedience to the lawful order of the serviceman, the militiaman);

- systematic - Commission of an offense within one year several times (more than 3 times), and in any one sphere, by the same subjects (for example, systematic violation by drivers of traffic rules).

In the current legislation of Ukraine on admittance nothing is specifically indicated in relation to the attempt on an administrative offense, as well as complicity in it.

Among the signs of the objective side of individual crimes, the legislator often points to the sign of "another person" (for example, malicious disobedience to the request of a police officer, molestation of foreign citizens, bringing minors to a state of intoxication, etc.).

${ }^{12}$ Course of administrative law of Ukraine: Textbook/ V. Kolpakov, O. Kuzmenko, I. Pastukh, V. Sushchenko / ed.. V. Kovalenko. Kyiv: Yurinkom Inter, 2012. 808 p. 
Sometimes separate legal signs of the objective party are included by the legislator directly in a construction of this or that legal norm and acquire qualifying value. These are signs concerning:

- time of Commission (for example, violation of silence at night, hunting in the forbidden terms);

- places of its Commission (for example, appearance in public places in a state of intoxication, drinking alcoholic beverages at work, hunting in prohibited places);

- conditions (for example, violation of certain sanitary-quarantine, technical, natural conditions, creation of conditions for holding mass events in violation of the established order);

- methods (for example, cruelty to animals, malicious evasion of appearance in court);

- means of committing an offense (for example, vehicles, prohibited hunting tools, drugs, etc.).

\section{CONCLUSIONS}

1. Offenses in essence covers all acts that violate the established law (in its broadest sense) the procedure for the implementation of rights, freedoms and interests, as well as the implementation of duties. Any discrepancy of actual circumstances to legal requirements shall be interpreted as an offense taking into account features of methods of legal regulation of public relations in which the rights, freedoms and interests are realized, duties are carried out.

Misconduct, in our opinion, must first of all be identified with the existence of prohibiting norms, which must clearly define acts that are indisputably recognized as socially harmful and socially dangerous. Now there is a need to legally consolidate the concepts of "offense" and "misdemeanor", which guarantees effective mechanisms associated with the effective implementation of citizens of their rights, freedoms and interests, as well as protect both the individual and society as a whole from socially harmful events caused by illegal actions of subjects.

2. An administrative offense (misdemeanor) is an illegal, guilty (intentional or careless) action or inaction that encroaches on public order, property, rights and freedoms of citizens, on the established order of management and for which the law provides for administrative responsibility (article 9 of the CAO).

The law contains two terms at the same time: "administrative offense" and "administrative offense", but the latter is not a special type of administrative offense. 
An administrative offense (misdemeanor) is characterized by a number of signs. It is, first, an act, behavior, act of a person, action or inaction, as well as an act of external expression of the person's attitude to the real activities of other people, society, and the state. The law is not subject to the beliefs, thoughts of people, if they have not found an external manifestation.

3. There are two types of administrative offenses:

- Most misdemeanors do not border on criminal offenses and under no circumstances will they escalate into crimes.

- Border crimes (for example, article 51, article 173 of the CAO).

We have no pronounced and clearly defined criteria that define a criminal offense and two groups of administrative offenses. Such a distinction should be made on certain grounds specified in the legislation. For example, petty theft of another's property (article 51 of the administrative code) and criminal theft (article 84 of the criminal code of Ukraine) are distinguished by the value of the stolen or the method of abduction. From the point of view of the legislator such differentiation should be carried out persons (taking into account character and personal features of the offender). Finally, administrative action is considered inaction (act) with the achievement of a certain result.

\section{SUMMARY}

Offences that today in theory, in practice and in legislation are understood as administrative, in theory, in practice and in legislation prerevolutionary Russia were understood as unimportant crimes or misdemeanors (police misdemeanors, torts).

Sanctions from their Commission carried out exclusively punitive functions provided in the criminal legislation, and their essence did not change neither from an administrative order of application, nor from establishment by administrative body. In the latter case, the administrative body established the composition of the acts and the punishment for their Commission.

Understanding of concepts of administrative (administrative) offense and administrative offense (tort) which in the legal theory of the Russian Empire were formed actually according to the European standards, after October, 1917 begin to change.

In official sources, they are gradually beginning to be interpreted as synonymous terms, meaning the acts of individuals who violate the prohibitions established by the state and entail an administrative procedure for the application of penalties.

In accordance with ideological and political attitudes, a doctrinal basis is developed. Legislative consolidation of this approach gets in the 
Fundamentals of the USSR and the Union republics on administrative offenses (1980), in article 7 used the following wording: "administrative offense (misdemeanor) is recognized...". Thus, the position of the legislator regarding the adequacy of the concepts of "administrative offense" and "administrative offense" was fixed.

\section{REFERENCES}

1. Administrative law of Ukraine. Academic course: Studies: / T. Kolomoets. Kyiv: Yurinkom Inter, 2011. 576 p.

2. Administrative law of Ukraine. Academic course: Studies: In 2 vols. / Ed. Collegium: V. Averyanov (head). Kyiv: Yuridicheskaya Mysl, 2004. Vol. Common part. $584 \mathrm{p}$.

3. Demsky, E. Administrative procedural law of Ukraine: studies. benefit. / E. Demsky. Kyiv: Yurinkom Inter, 2008. 496 s

4. Kolpakov V. Administrative responsibility (administrative-tort law): studies. no. / V. Kolpakov. Kyiv: Yurinkom Inter, 2008. 256 p.

5. Course of administrative law of Ukraine: Textbook/ V. Kolpakov, O. Kuzmenko, I. Pastukh, V. Sushchenko / ed. V. Kovalenko. Kyiv: Yurinkom Inter, 2012. $808 \mathrm{p}$.

6. Scientific and practical comment of section IV "Powers of police" and V "Police measures" of the Law of Ukraine "on National police" / T. Minka, G. Mironyuk, V. Glukhoverya, etc.; for zag. ed. Kharkiv: Pravo, 2016. 178 p.

7. National police. A temporary web site. URL: http://www.npu.gov.ua/uk/

8. Official website of the Ministry of internal Affairs of Ukraine. URL: http://www.mvs.gov.ua Official website of the Ministry of internal Affairs of Ukraine. URL: http://www.mvs.gov.ua/.

Information about the author: Popovich Ye. M., Doctor of Law, Professor, Professor at the Department of Administrative, Criminal Law and Procedure, International University of Business and Law 37-A, 49 HGD str., Kherson, 73040, Ukraine 